\title{
ECOLOGY OF AMAZONIAN NEEDLEFISHES (BELONIDAE)
}

\author{
MICHAEL GOULDING \\ MIRIAN LEAL CARVALHO
}

\section{INTRODUCTION}

The Amazon Basin has about 15 families and over 60 species of fishes whose relatives are mostly marine (Roberts, 1972 gives a slightly lower estimate for the species). Supposedly the freshwater forms were derived from marine taxa, or at least their ancestors were. The Belonidae, or needlefishes, are represented by at least 10 genera and 32 species in the oceans and freshwaters of the world (Collette, 1974b; Nelson, 1976). South America has four freshwater belonid genera, three (Potamorrhaphis, Pseudotylosurus and Belonion) of which are endemic and one (Strongylura) that is worldwide in marine, estuarine and freshwaters (Collette, 1974b). In South America Pseudotylosurus appears to be the most widespread freshwater belonid genus, and is known from the Orinoco, Amazon and La Plata drainage systems and from rivers in the Guianas region (Collette, 1974c). Pseudotylosurus microps is found in the Orinoco and Amazon basins and in the Guianas; $P$. eigenmanni is known from the Paraná-Paraguay and upper Madeira areas (Collette, 1974c). Potamorrhaphis is distributed in the Orinoco and Amazon basins and in the Guianas region; $P$. petersi is known from the Amazon and Orinoco basins, whereas $P$. guianensis is found in these two systems and in the Guianas (Collette, 1974a, 1982). The genus Belonion is known from the Orinoco and Amazon Basins; $B$. dibranchodon appears to be restricted to the Orinoco system, and likewise, $B$. apodion to the Amazon drainage (Collette, 1966).

Needlefishes are so-named because of their greatly elongate jaws and bodies (Fig. 1). Morphologically, however, they resemble an arrow more than a needle, and the analogy is also more correct. The anal and dorsal fins are relatively small and lie posteriorly, just as feathers do on an arrow. Species of Pseudotylosurus and Potamorrhaphis reach at least $30 \mathrm{~cm}$ in total length, in contrast to Belonion whose largest members are only about $5 \mathrm{~cm}$. Belonion is also strikingly different because only the lower jaw is greatly elongate, whereas in all other known belonids both jaws are well developed, at least in adults.

In this paper we offer the first information on the ecology of Amazonian needlefishes, and furthermore, relate this data to the morphological structure of the fishes, and their hypothesized phylogeny. 


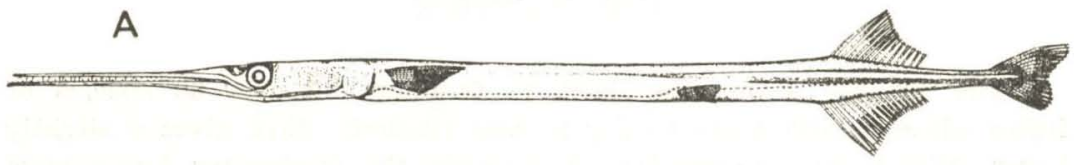

B

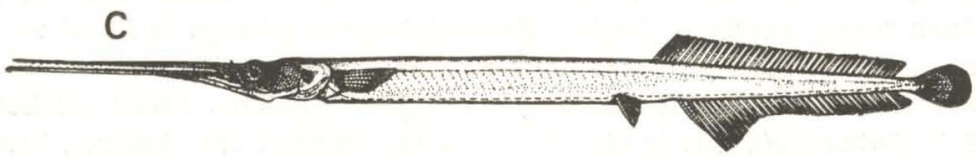

D

Figure 1 - A) Pseudotylosurus microps, $18 \mathrm{~cm}$; B) Potamorrhaphis guianensis, $10 \mathrm{~cm}$; C) Potamorrhaphis petersi, $13 \mathrm{~cm}$; D) Belonion apodion, $4 \mathrm{~cm}$. From Collette (1966, 1974-a, 1974-c). Illustrations courtesy of Dr. Bruce Collette. 


\section{STUDY AREA}

The study area focuses on the Rio Negro and Rio Tefé in the state of Amazonas, Brazil (Fig. 2). The Rio Negro is a northern affluent of the Rio Solimões-Amazonas, and also its largest tributary. The Rio Tefé is a southern tributary of the Rio Solimões, and enters this river about $500 \mathrm{~km}$ upstream from its confluence with the Rio Negro. Both the Rio Negro and Rio Tefé are blackwater rivers, that is, they transport minimal sediment loads, but their waters are nevertheless dark because they are stained by humic acids. The organic compounds coloring the Rio Negro are derived from vegetation growing on white sands (podzolic soils) whose litter is incompletely decomposed, thus allowing run-off to carry humic acids into the streams and main river (Klinge, 1965; Klinge \& Ohle, 1964). The origins of the humic acids in the Rio Tefé are unknown. The Rio Negro and Rio Tefé are extremely poor in nutrients, and are chemically very similar to rainwater (Gibbs, 1967, 1971; Sioli, 1967, 1968). Their pH's are usually below 5.0, though high acidity in itself does not appear to prevent herbaceous plant communities from developing, especially in floodplain areas where there have been recent tree and shrub die-offs. The invasion of aquatic macrophytes in these blackwater rivers appears to be a recent phenomenon, as neither Wallace (1853) nor Spruce (1908) reported them in the Rio Negro in mid-nineteenth century and local residents of the Rio Tefé told the first author that Paspalum, Oryza and other herbaceous taxa first appeared in this system about two decades ago. The floodplains of the Rio Negro and Rio Tefé are covered mostly by rainforest adapted to seasonal inundation.

Fish collections that were made by others but that were examined for this study included those from the lower Rio Solimões (Tlha Marchantaria), Rio Negro-Rio Solimões confluence (Paraná de Paracaúba), lower Rio Japurá (exact locality unknown) and Rio Aripuanã (Igarapé do Castanhal). Further details will be given later in the paper (also Fig. 2).

\section{MATERIALS AND METHODS}

Most of the specimens examined for this study were captured by the first author while making fish collections in the Rio Negro and Rio Tefé during 1979 and 1980. There was no special effort made to catch belonids, but they were taken with seines, dipnets and rotenone while collecting other fishes. Most of our material is from the low water periods, as we had no sucess catching belonids in flooded forest, where they apparently go during the inundation season. All together 151 belonid specimens were examined for stomach contents (the breakdown by species, locality and number of specimens of each species examined are indicated on Fig. 2). Fifteen of the specimens were from uncatalogued 


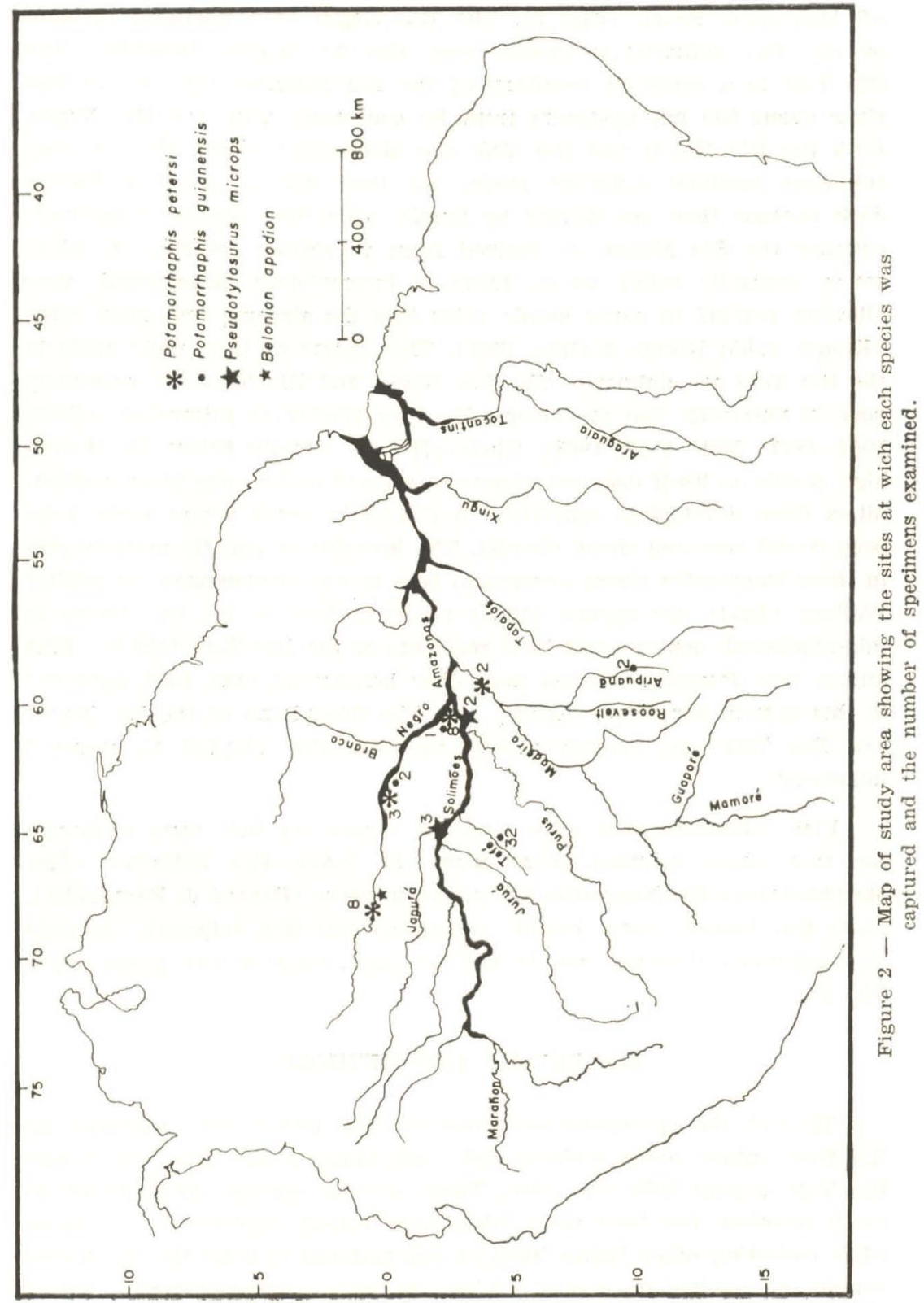


collections deposited at the Instituto Nacional de Pesquisas da Amazônia (INPA) in Manaus. Though more specimens for analysis would be desirable, the decision to publish the data at hand was based on the fact that no additional belonids could be obtained and that there is almost no information on the ecology of Amazonian needlefishes in the literature.

Both the stomachs and intestines of the belonids studied were analyzed for food contents. All food items were examined under a microscope. Analyses for Potamorrhaphis and Pseudotylosurus were made by identifying, separating and counting all of the food items found. Because Belonion has a more diverse feeding behavior than the above two genera, three methods - occurrence, dominance and volume were employed to study its food contents. Occurrence is calculated as the number of individuals in which a particular food item was present; likewise, dominance is calculated as the number of individuals in which a particular food item constituted the major part of the bulk. Volume is calculated from fullness multiplied by the percentages (expressed in intervals of .05 or .10) estimated to be the contributions of individual items found in the stomach and intestines. Thus, for example, an individual might be 50 percent full (fullness score of 50), of which 60 percent (.60) was zooplankton and 40 percent (.40) insect larvae; the volume for zooplankton and insect larvae would then be, respectively, 30 and 20. Mean fullness was calculated using all specimens, even those with empty stomachs.

\section{RESULTS}

\section{Belonion apodion}

A total of 80 specimens of $B$. apodion were analyzed for food contents. The specimens were collected at four different sites in the upper Rio Negro region; three of these were lakes located on island floodplains, and the fourth was a low-lying swampy area formed at the confluence of the Rio Urubaxi with the Rio Negro (see Fig. 2). In all three lake sites zooplankton was the major food item eaten, followed by insects (mostly larvae) or bryozoans (Tab. 1). At the Rio Urubaxi/Rio Negro swamp site, dipteran insect larvae accounted for the largest volume of food eaten, followed by zooplankton (Tab. 2). Mean fullnesses ranged between about 31 and 62 percent, with the highest two values for sites where zooplankton was the dominant food item eaten.

At two of the sites, cladocerans (especially Bosminopsis and Bosmina) were the principal zooplankton eaten, while at the other two rotifers were. Copepods were only found in specimens from two sites, and then in only small quantities. The large number of insects found in the Rio Urubaxi/Rio Negro specimens were mostly pupae of Diptera, but there was also a considerable number of winged adults. 
A Mean Fullness: 62 percent

12 specimens: $35-41 \mathrm{~mm}$ SL

\begin{tabular}{llll}
\hline FOOD I T E S & Occurrence & Dominance & Volume \\
\hline
\end{tabular}

ZOOPLANKTON

1. Bosminopsis deitersi (Cladocera) ...

2. Bosmina spp. (Cladocera) .........

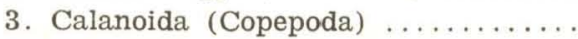

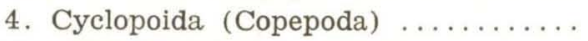

5. Keratella sp. (Rotifera) ..........

6. Lecane sp. (Rotifera) ............

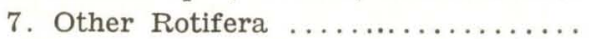

Sub-total of zooplankton ..........

INSECTS

1. Formicidae $\ldots \ldots \ldots \ldots \ldots \ldots \ldots \ldots$

2. Other insects $\ldots \ldots \ldots \ldots \ldots \ldots \ldots$

Sub-total of insects $\ldots \ldots \ldots \ldots \ldots \ldots$

$\begin{array}{rrr}9 & 3 & 159 \\ 9 & 1 & 134 \\ 1 & - & 15 \\ 3 & - & 15 \\ 8 & 2 & 168 \\ 3 & - & 7 \\ 8 & - & 7 \\ - & 6 & 505\end{array}$

OTHER FOOD ITEMS

1. Bryozoa ...................

$\begin{array}{lll}4 & 2 & 165\end{array}$

EMPTY ................

Total Volume .............. - - $\quad 750$

B Mean Fullness: 31 percent

4 specimens: $35-49 \mathrm{~mm}$ SL

\begin{tabular}{llll}
\hline F O O D T E M & Occurrence Dominance Volume
\end{tabular}

ZOOPLANKTON

1. Bosminopsis deitersi (Cladocera) ...

$\begin{array}{rrr}1 & - & 1 \\ 1 & 1 & 50 \\ 1 & - & 1 \\ - & 1 & 52\end{array}$

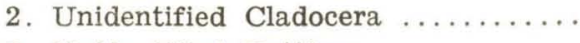

3. Unidentified Rotifera ............

Sub-total of zooplankton

OTHER FOOD ITEMS

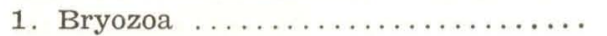

$\begin{array}{rrr}1 & - & 2 \\ 2 & 2 & 70 \\ - & 2 & 72 \\ 1 & - & - \\ - & - & 124\end{array}$

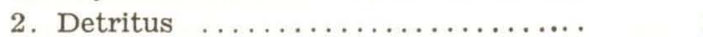

Sub-total of other food items ......

EMPTY $\ldots \ldots \ldots \ldots \ldots \ldots \ldots \ldots$

Total Volume

Mean Fullness: 62 percent

2 specimens: $31-43 \mathrm{~mm}$ SL

FOOD I TEM S

Occurrence

Dominance

Volume

ZOOPLANKTON

1. Lecane sp. (Rotifera)

2

1

95

INSECTS

1. Unidentified $\ldots \ldots \ldots \ldots \ldots \ldots \ldots \ldots 1$

EMPTY

1

1 


\section{T A B L E 2}

Stomach and intestine content analyses of Belonion apodion captured in a low-lying swampy area at the confluence of the Rio Urubaxi and Rio Negro. A total of 62 specimens, ranging between 31 and $44 \mathrm{~mm}$ standard length (as measured from the tip of the upper jaw to the hypurals) were examined. Mean fullness was 42 percent.

\begin{tabular}{llll}
\hline FOOD I TEM S & Occurrence & Dominance & Volume \\
\hline
\end{tabular}

\section{ZOOPLANKTON}

1. Bosminopsis deitersi (Cladocera) ...

2. Bosmina $\operatorname{spp}$ (Cladocera) .........

3. Chydoridae (Cladocera) ..........

4. Ephipia (Cladocera) ...........

5. Calanoida (Copepoda) ...........

6. Cyclopoida (Copepoda) ...........

7. Keratella sp. (Rotifera) .........

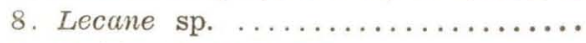

9. Unidentified Rotifera ..........

Sub-total of zooplankton

\section{INSECTS}

1. Diptera (pupae)

$\begin{array}{rrr}52 & 46 & 1405 \\ 16 & 9 & 487 \\ 5 & 4 & 105 \\ - & 59 & 1997\end{array}$

2. Diptera (winged adults) $\ldots \ldots \ldots \ldots$

3. Unidentified insects $\ldots \ldots \ldots \ldots \ldots$

Sub-total of insects

$\begin{array}{rrr}23 & - & 79 \\ 6 & - & 18 \\ 3 & - & 13 \\ 1 & - & 5 \\ 1 & - & 2 \\ 1 & - & 1 \\ 6 & 1 & 59 \\ 20 & - & 42 \\ 15 & - & 51 \\ - & 1 & 270\end{array}$

OTHER FOOD ITEMS

1. Bryozoa .................. 13

2. Acarinae ............... 1

3. Detritus $\ldots \ldots \ldots \ldots \ldots \ldots \ldots \ldots \ldots$.

4. Phytoplankton $\ldots \ldots \ldots \ldots \ldots \ldots \ldots . . \ldots$

Sub-total of other food items ..... -

$\begin{array}{rrr}13 & 1 & 113 \\ 1 & - & 1 \\ 22 & 1 & 181 \\ 3 & - & 28 \\ - & 2 & 323 \\ - & - & - \\ - & - & 2590\end{array}$

\section{T A BLE 1 (Left)}

Stomach and intestine content analyses of Belonion apodion captured in three lakes of the upper Rio Negro. A) inland lake near Barcelos; $B$ ) inland lake near Tapuruquara; C) inland lake near mouth of Rio 


\section{Pseudotylosurus microps}

No specimens of $P$. microps were obtained from the Rio Negro or Rio Tefé, though Collette (1974c) has examined specimens from the confluences of the Rio Negro with the Rio Solimões and the Rio Negro with the Rio Branco. The species is probably rare or absent in blackwaters in the mid-western/central Amazon. For comparative purposes, six specimens from the INPA collection were examined. Five of these contained fish in their stomachs. All five prey specimens had their heads bitten off, and these were also found in the stomachs. The prey to predator ratio (based on standard length) for the five prey specimens was the following: 11, 16, 18, 22 and 24 percent (mean= 18.2). None of the prey could be identified to genus because of digestion, but at least two of the quintet were characins.

\section{Potamorrhaphis guianensis}

Of the 42 specimens of $P$. guianensis examined, 32 were from the Rio Tefé, three from the Rio Negro, two from the Rio Aripuanã and one, from the INPA collection, was without any information. The specimens ranged between 15 and $29 \mathrm{~cm}$ in standard length. Fourteen of the specimens examined had empty stomachs and intestines, while all of the others, with one exception, contained only insects (Tab. 2). The unusual individual contained a $34 \mathrm{~mm}$ Nannostomus sp., but since both species were captured in the same seining, it may have been swallowed while in the net. Of the 60 individual insects eaten by 27 specimens of $P$. guianensis, 48 were ants (mostly winged forms), while the others identified included an aquatic hemipteran and an adult odonatan. One spider had also been eaten.

\section{Potamorrhaphis petersi}

Of the 24 specimens of $P$. petersi examined, 19 were from the Rio Negro, two were from the Rio Aripuanã and two unlabeled specimens were from the INPA collection. The specimens ranged between 15 and $26 \mathrm{~cm}$ in standard length. Insects had the highest occurrence, and were found in eight of the specimens. Winged ants were the most important insects eaten, and were found in five of the specimens; the only other insect identified was an orthopteran eaten by one individual. Fish had been eaten by six of the $P$. petersi examined. Prey that could be identifed were a larval Crenicichla sp. (31 $\mathrm{mm}$ standard length), an Apistogramma sp. (21 $\mathrm{mm}$ standard length) and two characins (both $12 \mathrm{~mm}$ standard length). The prey to predator length ratio (based on standard length) was the following: 7,8 and 16 percent (mean $=10.3$ ). One of the characins had its head bitten off, while the other prey were found whole in the stomachs. 
T A B L E 3

Stomach content analyses of Potamorrhaphis guianensis and $\mathrm{P}$. petersi P. guianensis

\begin{tabular}{c|c|c}
\hline FOOD ITEM & OCCURRENCE & $\begin{array}{c}\text { TOTAL.PREX } \\
\text { INDIVIDUALs }\end{array}$ \\
\hline Formicidae $\ldots \ldots \ldots \ldots \ldots \ldots \ldots \ldots \ldots \ldots$ & 19 & 48 \\
Hemiptera (aquatic) $\ldots \ldots \ldots \ldots \ldots \ldots$ & 1 & 1 \\
Odonata (adult) $\ldots \ldots \ldots \ldots \ldots \ldots \ldots$ & 1 & 1 \\
Unidentified insects $\ldots \ldots \ldots \ldots \ldots \ldots$ & 9 & $9 \ldots \ldots \ldots$ \\
Arachnids $\ldots \ldots \ldots \ldots \ldots \ldots \ldots \ldots$ & 1 & 1 \\
\hline
\end{tabular}

P. petersi

\begin{tabular}{|c|c|c|}
\hline Formicidae $\ldots \ldots \ldots \ldots \ldots \ldots \ldots$ & 5 & 7 \\
\hline Orthoptera $\ldots \ldots \ldots \ldots \ldots \ldots$ & 1 & 1 \\
\hline Unidentified insects $\ldots \ldots \ldots \ldots \ldots$ & 2 & 2 \\
\hline \multicolumn{3}{|l|}{ Fish } \\
\hline Crenicichla sp. .............. & 1 & 1 \\
\hline Apistogramma sp. ............. & 1 & 1 \\
\hline characins $\ldots \ldots \ldots \ldots \ldots \ldots \ldots$ & 2 & 2 \\
\hline Unidentified $\ldots \ldots \ldots \ldots \ldots \ldots \ldots$ & 1 & 1 \\
\hline
\end{tabular}

\section{DISCUSSION}

The two most salient characteristics of belonid morphology are elongate, tubular bodies and greatly extended jaws (or jaw in the case of Belonion). We hypothesize that the arrow-like morphology of Potamorrhaphis and Pseudotylosurus is an adaptation for high velocity strikes at prey. On numerous occasions the first author has observed Potamorrhaphis striking at what must have been prey (though the prey were never seen in the water). The same strike pattern was observed on all occasions, which was this. Potamorrhapis never attaked head-on, but usually at about a 90 to 150 degree angle, as measured from either eye. All strikes observed were launched from a stationary position, and not when the fish was swimming. The impression is that Potamorrhaphis do not actively purse prey, but wait for them to pass or fall into the water, at which time they strike. This is always close to the shore and near the surface. Before striking, Potamorrhaphis recurve their bodies (much like a bow) and then shoot (like an arrow) towards the prey. The recurvature of their bodies, before striking, would appear to give them the muscular tension needed to strike at high velocity. The strikes are so fast that the first author was never sure what the fishes were attacking. In the case of prey that are other fishes, the advantage of 
high speed strikes is obvious: to capture the animal before it defects the potential predator. In the case of the insect-eating Potamorrhaphis species, high speed strikes may be necessary to get food items that are intensively attacked by many other fishes as well, as the prey (mostly ants) present few obstacles to their capture once they have fallen in the water. Belonids appear to feed only during the day, and at night remain stationary near the shore, usually aligning themselves with submerged roots, branches or other vegetation. In the case of Strongylura timucu in the mangrove swamps of São Paulo, southeastern Brazil, Sazima and Uieda (1979) suggest that body alignment with submerged vegetation is protective resemblance and an adaptation against avian predators. The Rio Negro and Rio Tefé have low biomasses of piscivorous birds, and thus body alignment of belonids with vegetation, if it is anti-predatory in nature, must be an adaptation against fishes and perhaps caimans.

Elongate jaws of Amazonian fishes that are at least superficially similar to those of Potamorrhaphis and Pseudotylosurus are only found in the characin genera Boulengerella and Ctenolucius (family Ctenoluciidae). All Amazonian fishes with pincer-like jaws are carvivorous (Boulengerella has been studied by the first author - Goulding, in prep.). In contrast to ctenoluciids, belonids take smaller prey, and this behavior is also suggested by needlefishes' finer and more elongate jaws. In the Rio Negro and Rio Tefé, Potamorrhaphis and Boulengerella inhabit the same biotopes (shore zones of deep and shallow waters) and small groups of both taxa are often encountered intermixed. The different feeding behaviors of these two taxa perhaps largely explain why they are able to live together. Potamorrhaphis, however, have been found in the stomach contents of Boulengerella, and thus any notion of protective mimicry appears to carry little weight in this case.

The genus Belonion is the most aberrant of all balonids because adults have a small upper jaw, which makes them resemble half-beaks (Hemiramphinae) more than adult needlefishes. Collette (1966) suggested that Belonion is a neotenic form because most belonids go through a "halfbeak" stage during ontogeny, and furthermore, that Belonion is not closely related to Potamorrhaphis of the extant needlefishes. The small insect larvae and zooplankton accounting for most of the diet of $B$. apodion are the same types of foods that one would imagine for young belonids. Unfortunately, we were unable to find any larval Potamorrhaphis or Pseudotylosurus, to verify this assumption. Furthermore, it has not been shown that larval Pseudotylosurus and Potamorrhaphis go through a "halfbeak" stage. In any case, we hypothesize that the shortened upper jaw of $B$. apodion, in addition to the small size of the fish, is an adaptation for feeding on zooplankton and small insect larvae. Zooplankton and insect larvae probably enter the mouth of $B$. apodion through suction, in great contrast to the physical manipulation of prey by adult Potamorrhaphis and Pseudotylosurus. The short upper jaw in $B$. apodion - and in the juvenile stages of other belonids as well allows a suction current to flow freely through the mouth (an elongate upper jaw would prevent this). 
Potamorrhaphis differs from Pseudotylosurus, Belonion and Strongylura in its more elongate dorsal and anal fins (see Fig. 1). In the Rio Negro, Potamorrhaphis were often observed in waters along deep shore zones (the bounce bank) where the current was fairly swift. Collette (1974b), reviewing the biotopes of where Strongylura hubbsi was captured in Central America, gives the impression that the species inhabits mostly quiet waters. The same seems to be true of $B$. apodion in the Rio Negro. The exact biotopes of Pseudotylosurus have not been reported. The evidence, as far as it goes, seems to suggest that the more elongate dorsal and anal fins of Potamorrhaphis may help with stabilization in the fast waters that the species inhabits, or at least which some populations do. It should be pointed out, however, that Boulengerella also inhabit these lotic biotopes, but that they have relatively small dorsal and anal fins, perhaps because they are stronger swimmers than belonids.

Amazonian belonids have a diverse feeding spectrum and evidence at least two types of behavior that are unknown for other fishes of the region. First, is the decapitation habit of Pseudotylosurus microps. Pseudotylosurus microps bites the heads of its prey, and at least one specimen of Potamorrhaphis petersi had done the same. This behavior would appear to be for killing the prey and/or eliminating its widest part, and not for shortening its length before ingestion, though it certainly serves all these functions. It would be instructive to know whether $P$. microps strikes at the head region of the prey - killing its victim instantly, as it were - or alternatively, grasps the fish in any manner possible, and then manipulates it in the jaws until it can be decapitated.

The second unusual feature of belonid feeding is found in the zooplankton eaten by Belonion apodion. Unlike other adult zooplanktivorous fishes, $B$, apodion consumes significant quantities of rotifers (rotifers are relatively rare in the oceans, thus the statement partains mostly to freshwater communities). Rotifers are among the smallest metazoan animals, and those found in $B$. apodion stomach and intestine contents were less than $0.1 \mathrm{~mm}$ in length. This may be compared to copepod and cladoceran lengths which exceeded $0.3 \mathrm{~mm}$. It is generally assumed that zooplankton feeding fishes do not capture rotifers because their small size allows them to pass through gillrakers and thus out through the gills. Because $B$. apodion lacks fine, numerous gillrakers, there is no reason to believe that it is a filter feeder. More likely, it pecks at individual zooplankton and, because of its very small size, is able to take rotifers that are too diminutive to be captured in quantities by larger fishes.

Based on Collette's (1974a, 1974b, 1974c, 1976, 1982) extensive work on freshwater belonid taxonomy and morphology, we have constructed a cladogram suggesting phylogenetic relationships of Amazonian needlefishes (Fig. 3). The feeding behavior of four of the five Amazonian species is also indicated on the cladogram. We have found little information 


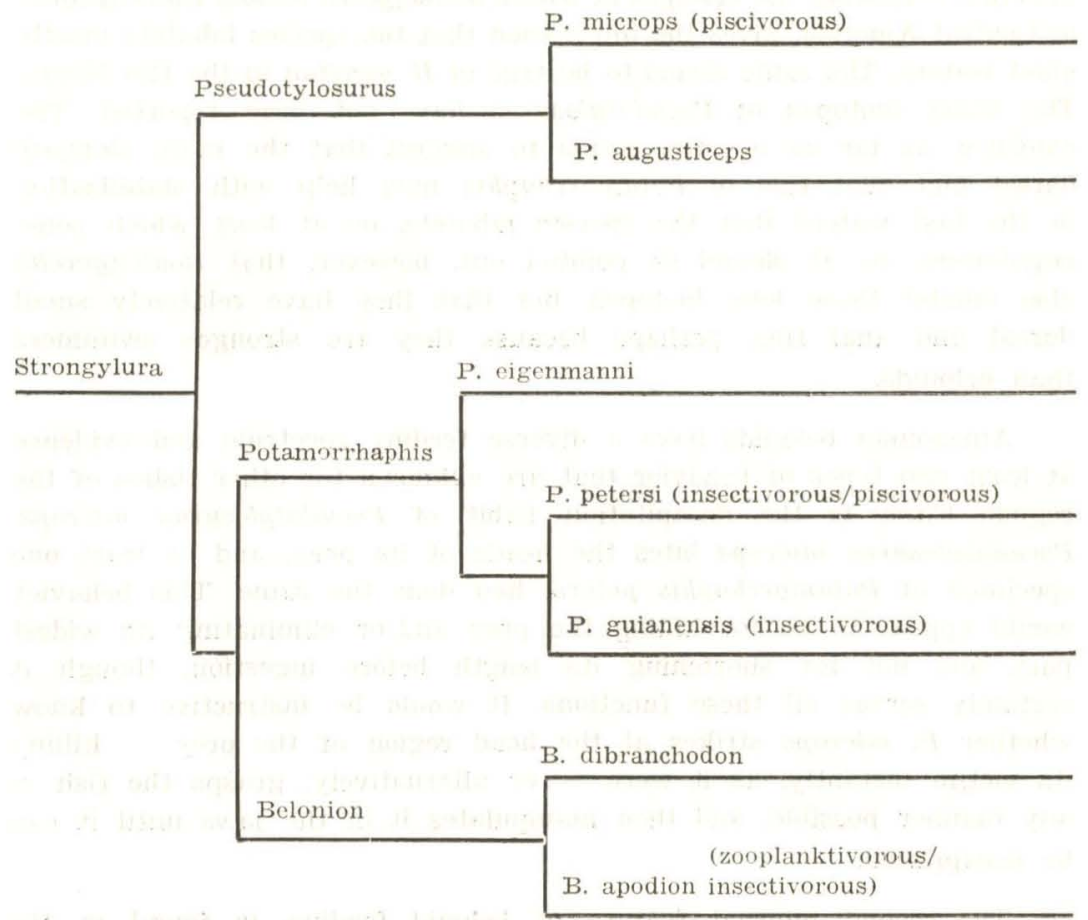

Figure 3 - Dendrogram suggesting the phyłogenetic relationships of South American freshwater needlefishes (Belonidae).

on the feeding behavior of Strongylura, hypothetically the most primitive freshwater belonid genus of South America (Collette, 1966), though Sazima \& Uieda (1979) state that S. timucu, a brackish water species, feeds on fish and shrimp. Nevertheless, it appears safe to hypothesize that the most primitive forms (that is, most closely related to marine ancestral taxa) are largely piscivorous (as suggested by our limited data on Pseudotylosurus microps). The other phylogenetic line, which led to Potamorrhaphis and Belonion, evolved feeding habits partially ( $P$. petersi), largely ( $P$. guianensis) or totally (B. apodion) outside of piscivory. If there is a trophic trend in Amazonian belonid phylogeny, then it has been from piscivory to insectivory and zooplanktivory. 


\section{ACKNOWLEDGMENTS}

We wish to thank Dr. Bruce Collette for helpful criticisms of the manuscript and Graça Overal for typing it. The research was financed by the Instituto Nacional de Pesquisas da Amazônia (INPA) and World Wildlife Fund.

\section{REFERENCES}

Collette, B. B., 1966. Belonion, a new genus of fresh-water needdlefishes from South America. Amer. Mus. Novitates 22\%4: 1-22.

Collette, B. B., 1974a. Potamorrhaphis petersi, a new species of freshwater needlefish (Belonidae) from the upper Orinoco and Rio Negro. Proc. biol. Soc. Wash. 87 (5) : 31-40.

Collette, B. B., 1974b. Strongylura hubbsi, a new species of freshwater needlefish from the Usumacinta Province of Guatemala and México. Copeia 3: 611-619.

Collette, B. B., 1974c. South American freshwater needlefishes (Belonidae) of tre genus Pseudotylosurus. Zool. Mededel. 48 (16): 169-186.

Collette, B. B., 1982. South American freshwater needlefishes of the genus Potamorrhaphis (Beloniformes: Belonidae). Proc. biol. Soc. Was. 95 (4): 714-747.

Gibbs, R. J., 1967. The geochemistry of the Amazon river system: Part. I. The factors that control the salinity and the composition of the suspended solids. Bull. Geol. Soc. Am. 78: 1203-1232.

Gibbs, R, J., 1971. Amazon river environmental factors that control its dissolved and suspended load. Science 156: 1734-1737.

Goulding, M., In prep. The predatory habits of Boulengerella (Ctenoluciidae).

Klinge, H., 1965. Podzol soils in the Amazon basin. J. Soil Sci. 16: 95-103.

Klinge, H. \& W. Ohle, 1964. Chemical properties of rivers in the Amazonian area in relation to soil conditions. Verh. int. Ver. Limnol. 15: 1067-1076.

Nelson, J. S., 1976. Fishes of the World. John Wiley \& Sons, New York.

Roberts, T. R., 1972. Ecology of fishes in the Amazon and Congo Basins. Bull. Mus. Zool. Harvard 143 (2): 117-147.

Sazima, I. \& V. S. Uieda, 1979. Is the night-time resting behavior of young needlefish an example of nocturnal disguise? Biotropica 11 (4): 308-309.

Sioli, H., 1967. Studies in Amazonian waters. Atas do Simpósio sobre a Biota Amazonica 3: 9-50.

Sioli, H., 1968. Hydrochemistry and geology in the Brazilian Amazon region. Amazoniana 1 (3): 267-277.

Spruce, R., 1908. Notes of a Botanist on the Amaron and Andes. Macmillan, London (A. R. Wallace, ed.).

Wallace, A. R., 1853. A Narrative of Travels on the Amazon and Rio Negro. Reeves, London. 